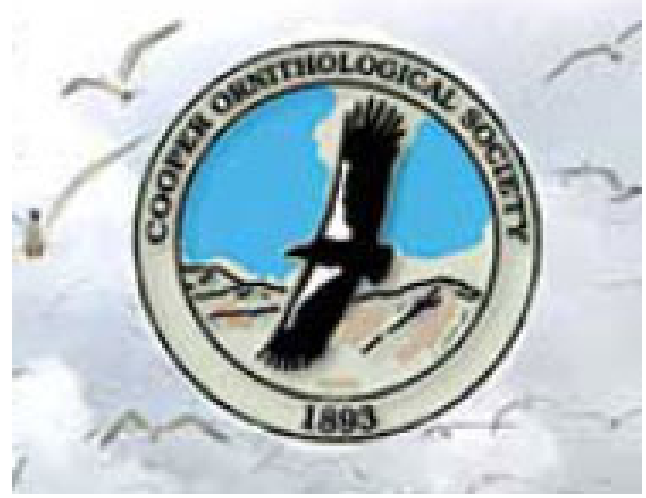

Corvids Using Objects to Displace Gulls from Nests

Author(s): W. A. Montevecchi

Source: The Condor, Vol. 80, No. 3 (Autumn, 1978), p. 349

Published by: University of California Press on behalf of the Cooper Ornithological Society

Stable URL: http://www.jstor.org/stable/1368052

Accessed: 25/06/2013 13:28

Your use of the JSTOR archive indicates your acceptance of the Terms \& Conditions of Use, available at

http://www.jstor.org/page/info/about/policies/terms.jsp

JSTOR is a not-for-profit service that helps scholars, researchers, and students discover, use, and build upon a wide range of content in a trusted digital archive. We use information technology and tools to increase productivity and facilitate new forms of scholarship. For more information about JSTOR, please contact support@ jstor.org.

University of California Press and Cooper Ornithological Society are collaborating with JSTOR to digitize, preserve and extend access to The Condor. 


\section{CORVIDS USING OBJECTS TO DISPLACE GULLS FROM NESTS}

\section{W. A. MONTEVECCHI}

Tool use (i.e., the use of a moveable, inanimate, noninternally manufactured object to facilitate the acquisition of a goal; McGrew et al. 1975) has been documented for many avian species (van LawickGoodall 1970) including several corvids (Orenstein 1972, Jones and Kamil 1973, Powell and Kelly 1975, Janes 1976). I report here two observations of corvids, a Fish Crow (Corvus ossifragus) and a Common Raven (C. corax), attempting to displace nesting gulls by using objects.

Fish Crows and Common Crows (C. brachyrhynchos) prey extensively on the eggs of Laughing Gulls (Larus atricilla) and Clapper Rails (Rallus longirostris) in the marsh of the Brigantine National Wildlife Refuge, New Jersey (Montevecchi 1977), often taking advantage of human disturbances in the nesting areas. On 6 June 1974, a Fish Crow with a 10$\mathrm{cm}$ stalk of dried salt marsh grass (Spartina alterniflora) in its beak flew directly toward an incubating Laughing Gull near an observation blind in which I was working. The crow hovered about $5 \mathrm{~m}$ above the nest, and then, passing the stalk from its beak to its feet, descended to about $3-4 \mathrm{~m}$. The gull, focusing intently on the hovering crow, became progressively more aroused; it called loudly, erected its plumage, and arose from the eggs. The crow dropped the stalk toward the gull. Owing to a brisk breeze, the stalk landed about $1 \mathrm{~m}$ from the gull, who remained on the nest. The crow flew off and did not return for the remainder of the observation period (90 min). Had the stalk struck (or landed nearer) the gull, the highly agitated bird probably would have fled the nest. No predation occurred at this nest during the subsequent week when it was checked, and I saw no similar behavior by crows.

On 12 June 1977, on Baccalieu Island, Newfoundland, I observed a Common Raven on a cliff perched about $1 \mathrm{~m}$ above a Black-legged Kittiwake (Rissa tridactyla) sitting on a nest. The raven called loudly at the aroused kittiwake, who behaved like the Laughing Gull described above. After about one minute, the raven pulled a tuft of dried grass from sod on the cliff face and dropped it on the gull. When the grass hit the kittiwake, the bird took flight, and the raven jumped down and rummaged through the empty nest. Ravens on Baccalieu Island frequently supplant nesting kittiwakes by suddenly approaching them closely while calling loudly, or sometimes by physical attack. Ravens often pull grass from the cliff face, though I only once saw a raven drop the grass on a gull. Janes (1976) reported a raven dropping rocks on human intruders near its nest. If hunting tactics such as those reported here are successful, it is likely that they will be used more frequently and may be rapidly adopted by other corvids hunting in the same places (see Hinde and Fisher 1951).

\section{LITERATURE CITED}

Hinde, R. A., AND J. Fisher. 1951. Further observations on the opening of milk bottles by birds. Br. Birds 44:393-396.

JANES, S. W. 1976. The apparent use of rocks by a raven in nest defense. Condor 78:409.

Jones, T. B., AND A. C. KamIL. 1973. Tool-making and tool-using in the Northern Blue Jay. Science 180:1076-1077.

McGrew, W. C., G. Tutin, and P. S. Midgett, Jr. 1975. Tool use in a group of captive chimpanzees. I. Escape. Z. Tierpsychol. 37:142-165.

MontevecchI, W. A. 1977. Predation in a salt marsh Laughing Gull colony. Auk 94:580-583.

Orenstein, R. I. 1972. Tool-use by the New Caledonian Crow (Corvus moneduloides). Auk 89: 674-676.

Powell, R. W., AND W. Kelly. 1975. A method for the objective study of tool-using behavior. J. Exp. Anal. Behav. 24:249-253.

van Lawick-Goodall, J. 1970. Tool-using in primates and other vertebrates. In $\mathrm{D}$. S. Lehrman, R. A. Hinde, and E. Shaw [eds.], Advances in the study of behavior. 3:195-250. Academic Press, New York.

Department of Psychology, Memorial University of Newfoundland, St. John's, Newfoundland AlC 5S7 Canada. Accepted for publication 21 February 1978. 